\title{
PENGARUH KOMUNIKASI INTERPERSONAL DALAM MENURUNKAN PROBLEM TEKANAN EMOSI BERBASIS GENDER
}

\author{
Hasyim Hasanah \\ Universitas Islam Negeri (UIN) Walisongo Semarang \\ e-mail: hasyimhasanah_82@yahoo.co.id
}

\begin{abstract}
This research seeks to investigate the contribution interpersonal communication to reduce emotion problem pressure college student in IAIN special programme. Five major dimension of interpersonal communication are openness, emphaty, supportiveness, positiveness and equality, were derived from a humanistic perception. Emotion problem pressure was defined in term pleasant and unpleasant emotion, besides from four conditional are stimulate, feelness, internal responshipness and behavior types. Sixty six subjects were involved in study, subject were devided into three programmes, 17 subject PKPA, 24 subject FUPK-TH and 25 subject FUPK-TP. To find the contribution between interpersonal communication and emotion problem pressure it used simple regression method, and different effect variables using t-test method. The result of this study shows that interpersonal communication has a real effect to reduce emotion problem pressure $\left(\mathrm{Fh}=7,966>\mathrm{Ft}=6,302, \mathrm{p}=0,05 ; \mathrm{R}^{2}=0,910\right)$, the contribution variation of interpersonal communication is high $(91,0 \%)$ and 0,9 explained by other variation models in independent variable. The contribution effect, male is higher than female $\left(t_{m}=16,065>t_{f}=\right.$ $11,660)$. In conclusion, interpersonal communication has the contribution effect to reduce emotion problem pressure of callege student in IAIN special programme.
\end{abstract}

Keywords: interpersonal; communication; emotion; problem pressure

\section{A. Pendahuluan}

Komunikasi merupakan kebutuhan setiap manusia, khususnya dalam menjalin interaksi kemanusiaan dan memenuhi kebutuhan hidup manusia. Pola komunikasi yang berkembang tidak hanya bersifat informatif tetapi juga persuasif. Artinya komunikasi tidak hanya bertujuan agar orang lain mengerti, tetapi juga berharap agar orang lain menerima suatu paham, 
keyakinan atau melakukan suatu perbuatan tertentu. ${ }^{1}$ Komunikasi yang dilakukan pada dasarnya memiliki empat fungsi yaitu fungsi sosial, ekspresif, ritual dan instrumental. Diantara fungsi komunikasi tersebut nampaknya tidak sama sekali independen, melainkan saling berkaitan satu dengan lainnya, meskipun terdapat fungsi komunikasi yang dominan, salah satunya adalah fungsi sosial untuk membangun konsep diri, aktualisasi diri, untuk kelangsungan hidup, memperoleh kebahagiaan, terhindar dari tekanan dan ketegangan serta memupuk hubungan dengan orang lain. ${ }^{2}$

Dalam menjalin interaksi dengan orang lain, komunikasi dikatakan efektif apabila ditandai dengan hubungan interpersonal yang baik. Sedangkan kegagalan komunikasi terjadi apabila isi pesan kita dipahami orang, tetapi juga pada hubungan diantara pelaku komunikasi itu sendiri. Hubungan komunikasi ini merupakan bentuk komunikasi interpersonal. Komunikasi interpersonal merupakan salah satu bentuk komunikasi yang sering dilakukan, menurut Gerald R Miller (1989) komunikasi interpersonal merupakan jenis komunikasi yang terjalin secara harmonis dimana masingmasing pelaku komunikasi dapat bertindak sebagai komunikator mapun komunikan secara bergantian dan dilingkupi dinamika psikologis yang begitu mendalam secara face to face. ${ }^{3}$ Tujuan penting komunikasi interpersonal diarahkan pada enam hal yaitu mengenal diri sendiri dan orang lain, mengetahui dunia luar, menciptakan dan memelihara hubungan, mengubah sikap dan perilaku, mencari hiburan dan membantu orang lain. Menurut Joseph N Cappella (1963) dalam Gerald R Miller disebutkan bahwa komunikasi interpersonal yang dilakukan pada tingkatan tertentu dapat melahirkan suasana dan dinamika psikologis yang dapat memberikan manfaat pada kebutuhan psiko-emosional manusia. ${ }^{4}$ Kebutuhan psiko-emosional tersebut meliputi adanya perasaan keterbukaan, empati, sikap suportif, sikap positif dan kesetaraan, cinta, kasih sayang, penghargaan, ketenangan dan kepercayaan. ${ }^{5}$ Lebih lanjut dijelaskan bahwa manusia secara psikis memiliki

1Onong Utjana Effendi, Ilmu Komunikas: Teori Komunikasi dan Praktek, (Bandung: PT. Rosdakarya, 1996), h. 9.

${ }^{2}$ Dedy Mulyana, Ilmu Komunikasi, (Bandung: PT. Rosdakarya, 2002), h. 5.

${ }^{3}$ Alaluddin Rahmad, Psikologi Komunikasi, (Bandung: PT. Rosdakarya, 2000), h. 119.

${ }^{4}$ Gerald $\mathrm{R}$ Miller, Exploration in Interpersonal Communication, (London: SAGA Publications, 1989), h. 59.

5Jalaludin Kafie, Psikologi Dakwah, (Surabaya: PT. Indah Offset, 1993), h. 121. 
kecenderungan terhambatnya kebutuhan psiko-emosional yang mengakibatkan dirinya mengalami tekanan emosi yang berupa kecemasan, prasangka, rasa takut, khawatir dan was-was, marah, agresif dan anarkis.

Problem tekanan emosi yang dihadapi manusia semakin berkembang sejalan dengan meningkatnya kebutuhan hidup manusia. Tekanan emosi merupakan situasi identik dengan ketegangan. ${ }^{6}$ Ketegangan emosi merupakan gejala afektif pada kejiwaan manusia yang dihayati secara subjektif, bersentuhan secara langsung dengan gejala pengenalan diri. William James mengatakan bahwa tekanan emosi merupakan dampak reaksi khas yang secara memndalam sebagai hasil reaksi suatu perkara, peristiwa, dan pengalaman yang terjadi pada diri individu dimana keadaan jiwa manusia dalam keadaan tertekan emosinya. ${ }^{7}$ Ketika manusia dalam kondisi tertekan biasanya akan diiringi banyak perubahan fungsi fisiologis dan kondisi fisik. Tekanan emosi timbul disebabkan adanya gejala psikis manusia dari faktor dasar (watak, kepribadian, karakter dan hereditas), lingkungan serta sesuatu yang berkembang menjadi berbagai emosi komplek karena usia, pengalaman, proses diferensiasi dan kondisi psikis yang tidak menentu. ${ }^{8}$ Bagi sebagian manusia tekanan emosi dapat diantisipasi dan disalurkan dengan tepat, tapi tidak jarang diantara mereka justru mengalami tekanan yang semakin berat dan komplek sehingga berdampak pada penurunan potensi atau tingkat kognitif atau kemampuan berfikirnya. Salah satu problem tekanan emosi yang komplek dialami oleh mahasiswa.

Mahasiswa merupakan salah satu masa pencarian identitas diri. Dimana seorang mahasiswa dituntut tidak hanya berkembang menjadi individu dewasa secara sosial, melainkan juga mengemban tugas-tugas akademik, mahasiswa dituntut untuk berpikir kritis dan produktif. ${ }^{9}$ Namun tugas perkembangan itu nampaknya belum sepenuhnya dicapai oleh mahasiswa. Pada tahun 2009 Dirjen Pendidikan Tinggi Islam Kementerian Agama RI menyelenggarakan program terobosan baru dalam rangka pe-

${ }^{6} \mathrm{H}$. Kaplan, Psychology Stress Trend In Theory And Research, (NewYork: Academic Press, 1983), h. 296.

7Florance Wedge, Mencegah Gangguan Emosional, disadur oleh Jc. Widyokartono dan MS Hadisubrata, (Jakarta: Obor, 1995), h. 332.

8Jalaludin Kafie, Psikologi Dakwah, h. 53.

${ }^{9}$ E.B Hurlock, Psikologi Perkembangan: Suatu Pendekatan Sepanjang Rentang Kehidupan, (terj.), (Jakarta: Erlangga, 1980), h. 339. 
nguatan jurusan langka peminat di PTAIN seluruh Indonesia dimana seluruh pembiayaan pendidikan ditanggung oleh Negara dalam hal ini Kementerian Agama RI. Adapun PTAIN yang ditunjuk untuk menyelenggarakan program ini berjumlah 21 (dua puluh satu) Perguruan Tinggi Islam Negeri terdiri dari 4 (empat) UIN, 8 (delapan) IAIN dan 9 (Sembilan) STAIN.

IAIN Walisongo merupakan salah perguruan tinggi yang ditunjuk untuk menyelenggarakan program dengan memperoleh mendapatkan 3 (tiga) program studi yang terdiri dari Fakultas Dakwah prodi Bimbingan Penyuluhan Islam 1 (satu) kelas dan Fakultas Ushuluddin dengan prodi Tafsir Hadits 1 (kelas) dan prodi Tasawuf dan Psikoterapi Islam sebanyak 1 (satu) kelas. Sesuai dengan ketentuan penyelenggaraan program Direktorat Pendidikan Tinggi Agama Islam, Program pendidikan sepenuhnya didesain dengan memadukan atau mengintegrasikan kegiatan akademik dan non akademik yaitu (1) pembinaan ma'had dan (2) Pembinaan Halaqah. Kegiatan akademik dan non akademik dijalankan secara kontinu baik di kampus maupun di luar kampus (pondok pesantren) meliputi penguasaan bahasa asing, tafsir, tahfizhul Qur'an, dan pengembangan skill/keterampilan sesuai dengan program studi masing-masing. sebagai berikut. Integrasi kurikulum ma'had dan kuliah regular menjadi tantangan tersendiri buat mahasiswa program khusus ini, karena mereka memiliki beban lebih besar dibandingkan dengan kelas regular. Mereka dituntut untuk dapat mencapai prestasi akademik yang tinggi sehingga dapat menyelesaikan program sesuai ketentuan penyelenggaraannya.

Beberapa mahasiswa didapatkan catatan penting bahwa diantara mereka mengalami problem psiko-emosional berupa kekhawatiran tidak mampu menyelesaikan program sesuai target yang ditetapkan. Beberapa mahasiswa yang teridentifikasi tekanan emosi dapat ditinjau daam perspektif gender yaitu dari jenis kelamin laki-laki dan perempuan. Sebagian besar laki-laki mengaku merasa terbebani dengan beban kurikulum akademik dan non akademik, mereka mengalami stress, bahkan tak jarang ada diantara mereka menjadi tertekan dan depresi. Sedangkan sebagian besar mahasiswa perempuan cenderung tidak mengalami hal tersebut. Tekanan psiko-emosional para mahasiswa laki-laki lainnya berupa rasa minder, malu terhadap kelompoknya, hal ini terjadi karena penurunan prestasi belajar sehingga berdampak pada sikap mulai menarik diri dari komunitasnya dan 
suka menyendiri. Kondisi ini nampaknya dapat menimbulkan situasi yang tidak kondusif, harmonis dan menimbulkan ketegangan yang hebat di satu ada tuntutan untuk mencapai prestasi akademik tinggi, di sisi lain mereka juga harus mampu menyelesaikan program tepat waktu.

Kenyataan ini dapat diasumsikan bahwa mahasiswa program khusus kajian keislaman di IAIN Walisongo mengalami problem tekanan emosi. Bahkan hal ini dikuatkan dengan semakin berkurangnya jumlah mahasiswa program khusus di IAIN Walisongo. Masalah problem tekanan emosi yang dihadapi mahasiswa program khusus di IAIN Walisongo tidak boleh dibiarkan begitu saja. Diperlukan formulasi yang dapat menghadirkan semangat dan meghadirkan kondisi psiko-emosional yang harmonis, sehingga mereka yang dalam kondisi tegang, khawatir, minder, putus asa, dan belum mampu mencapai prestasi tinggi dapat memiliki motivasi dan semangat yang tinggi serta selalu menghadirkan nilai positif dalam aspek psiko-emosionalnya.

Salah satu upaya yang diduga mampu melahirkan kondisi psikoemosional yang harmonis, sehingga menimbulkan motivasi, semangat berprestasi dan menghadirkan nilai positif adalah dengan mengoptimalkan kebutuhan sosial mereka melalui efektivitas komunikasi interpersonal. Berdasarkan fungsi sosial komunikasi interpersonal sebagaimana dijelaskan di depan, nampaknya komunikasi interpersonal dapat membangun konsep diri, aktualisasi diri, untuk kelangsungan hidup, memperoleh kebahagiaan, terhindar dari tekanan dan ketegangan (emosi) serta memupuk hubungan sosial dengan orang lain. Hal ini dikarenakan komunikasi interpersonal merupakan salah satu bentuk komunikasi yang paling mudah dan sering dilakukan oleh setiap manusia. Berdasarkan latar belakang di atas, maka saya tertarik untuk melakukan penelitian ini.

\section{B. Konsep Teoritik}

Secara teoritik penelitian ini menggunakan pendekatan psikologi komunikasi. dimana secara psikolos komunikasi interpersonal yang dilakukan individu memiliki implikasi psikologis tertentu. Implikasi psikologi ini apabila dilakukan secara positif dan efektif akan melahirkan aspek keterbukaan, kedekatan sehingga dapat difungsikan sebagai teknik terapiutik.

\section{Pengertian dan Prinsip Komunikasi Interpersonal}

Definisi komunikasi interpersonal secara sederhana dikemukakan oleh Effendy yaitu komunikasi antara seorang komunikator dengan seorang 
komunikan. ${ }^{10}$ Komunikasi interpersonal juga dipahami sebagai komunikasi orang-orang secara tatap-muka yang memungkinkan setiap pesertanya menangkap reaksi orang lain secara langsung, baik secara verbal maupun nonverbal. Bentuk khusus dan komunikasi interpersonal ini adalah komunikasi diadik yang melibatkan hanya dua orang, seperti suami-istri, dua sejawat, dua sahabat dekat, guru-murid, dan sebagainya ditandai dengan pihak-pihak yang berkomunikasi berada dalam jarak yang dekat; pihakpihak yang berkomunikasi mengirim dan menerima pesan secara simultan dan spontan, baik secara verbal ataupun nonverbal. ${ }^{11}$

Secara lebih rinci Hovland mendefinisikan komunikasi interpersonal sebagai suatu keadaan interaksi ketika seorang (komunikator) mengirimkan stimuli (biasanya simbol-simbol verbal) untuk mengubah tingkah laku orang lain (komunikan), dalam sebuah peristiwa tatap muka. ${ }^{12}$ Komunikasi interpersonal merupakan komunikasi antara dua orang yang terjalin dalam suasana psikologis yang mendalam dan biasanya dilakukan secara tatap muka. Disebutkan pula tujuh ciri komunikasi interpersonal yaitu 1). Jumlah orang yang terlibat sangat sedikit (berkisar 2 atau 3 orang); 2). Tingkat kedekatan fisik pada waktu berkomunikasi intim sampai pribadi; 3). Sifat umpan baliknya segera; 4). Peran komunikasinya informal; 5). Penyesuain pesan bersifat khusus; 6). Tujuan dan maksud komunikasi tidak berstruktur namun sangat sosial. ${ }^{13}$ Sementara Wiryanto menjelaskan prinsip komunikasi antarpribadi yang bertolak belakang dengan komunikasi massa. Prinsip komunikasi antar pribadi tersebut adalah 1). Alur pesan yang berlangsung dua arah baik dari pengirim maupun penerima pesan; 2). Komunikasi berlangsung dalam suasana yang akrab atau lebih personal; 3). Umpan balik segera dapat diperoleh; 4). Lebih efektif mempengaruhi sikap dan perilaku; dan 5). ${ }^{14}$ Dari beberapa definisi di atas dapat disimpulkan bahwa komunikasi interpersonal adalah komunikasi yang terjadi antara

${ }^{10}$ Onong Utjana Effendi, Ilmu Komunikas: Teori Komunikasi dan Praktek, h.18.

${ }^{11}$ Mengapa kita berkomunikasi, http://www.coremap.or.id/downloads/Mengapa _Kita_Berkomunikasi, diunduh Senin, 10 Oktober 2011, jam 09.07 WIB.

${ }^{12}$ C.I Hovland \& W. Weiss, "The influence of Source Credibility on Communication Effectivennes", POQ 15, 1951, h. 341.

${ }^{13}$ Liliweri (1988) dalam Gerald Miller, Exploration in Interpersonal Communication, h. 45. 1976).

${ }^{14}$ Kelly G, The Pshycology of Personal Construct, (Lincoln: University of Nebrasca Press, 
komunikator dan komunikan, umumnya dalam suasana tatap muka dan umpan balik dapat langsung diamati oleh komunikator.

\section{Dinamika Komunikasi Interpersonal}

Menurut Hovland dan Lasswell dalam Rakhmad, Komunikasi interpersonal merupakan salah satu bentuk komunikasi yang memiliki dinamika psikologis tertentu. Keberadaan komunikasi interpersonal mampu melahirkan pola hubungan interaksional yang harmonis dan simbiosis. ${ }^{15}$ Bagi sebagian orang komunikasi interpersonal berubah menjadi pola hubungan kekerabatan, pertemanan dan persaudaraan. Para pelaku komunikasi dapat menjadikan dirinya sebagai subjek sekaligus objek komunikasi.

Dinamika komunikasi interpersonal meliputi adanya kesadaran konteks (lingkungan), pengelolaan bahasa alami, perangkat dunia maya, dan pembelajaran statistik. Komunikasi interpersonal menghasilkan dinamika psikologis yang mempengaruhi kerangka kerja dan perilaku hubungan interpersonal individu, adapun dinamika psikologis yang terbentuk dari proses komunikasi interpersonal ini meliputi kesadaran konteks lingkungan, pengelolaan bahasa informasi, perangkat lunak memperguna-kan efek dunia maya, serta mencapai teori belajar statistik, dan kemudian individu akan memiliki pemahaman dan penafsiran terhadap bahasa statistik dari kode, pengalih sandian informasi dan berakhir pada munculnya perilaku sesuai dengan tujuan komunikasi. Untuk mengukur dinamika psikologis dari komunikasi interpersonal dijabarkan dalam lima dimensi yaitu keterbukaan, empati, sikap suportif, sikap positif dan kesetaraan, yang nantinya akan dijabarkan dalam beberapa indikator.

\section{Problem Tekanan Emosi Laki-Laki dan Perempuan}

Memahami tekanan emosi secara teoritik dalam psikologi maka tidak bisa lepas dari Kaplan. Emosi sendiri berasal dari kata emotus atau movere yang berarti mencerca, menggerakkan (to stir up) yaitu suatu yang mendorong sesuatu muncul dari dalam diri manusia. Emosi merupakan kondisi penyesuaian organism sebagai akibat menghadapi situasi tertentu, sehingga emosi disebabkan gejala psikis. ${ }^{16}$ Emosi juga dipahami sebagai

${ }^{15}$ W.B Pearce, "Consensual Rule in Interpersonal Communications and Relationship", Journal of Communication, No. 23, 1973, h. 167.

16Jalaludin Kafie, Psikologi Dakwah, h. 53. 
suatu keadaan dan kecenderungan seseorang memiliki perasaan yang khas bila berhadapan dengan objek tertentu dalam lingkungannya. ${ }^{17}$ Kaplan menyebutkan bahwa emosi merupakan ekspresi dari tekanan atau akibat kegagalan individu menyesuaikan diri dengan lingkungan sekitarnya. ${ }^{18}$ Kegagalan individu menyesuaikan diri dengan lingkungan akan menyebabkan perasaan putus asa, merasa tidak puas dan tidak dapat membahagiakan diri sendiri khususnya dalam memenuhi kebutuhan hidupnya, seterusnya ia akan mengakibatkan seseorang mengalami ketegangan yang begitu berat.

Emosi dalam hal ini identik dengan ketegangan sebagai akibat gejala afektif pada kejiwaan manusia dihayati secara objektif dan bersentuhan secara langsung dengan gejala pengenalan diri. Dalam realitas terdalam, emosi bersifat tidak tetap baik bentuk maupun kadarnya. Menurut Fauzan, emosi memiliki ruang cukup luas, meliputi setiap keasaan pada diri seseorang yang disertai dengan warna afektif, baik pada tingkatan yang lemah atau pada tingkatan yang kuat. ${ }^{19}$ Menurut William James emosi merupakan dampak perasaan terdalam sebagai hasil reaksi suatu perkara, pengalaman, dan peristiwa yang berlaku seperti perasaan takut, marah, kecewa, gembira, suka dan kasih sayang. ${ }^{20}$ Oleh karena itu tekanan emosi ditakrifkan dengan keadaan seseorang dalam keadaan tertekan emosinya akibat peristiwa, pengalaman, atau beban tugas di luar batas kemampuan psikologis mereka.

Dalam dakwah islamiyah, tekanan emosi merupakan perasaan resah, gelisah, tidak tenang, cemas, was-was, sedih, kecewa, berduka cita, selalu menuruti hawa nafsu dan melanggar perintah Allah. ${ }^{21}$ Emosi merupakan wujud dari ketakutan manusia karena hati manusia tidak beriman, disamping itu tekanan juga dikaitkan dengan ketakutan, marah, benci, cinta dan penyakit hati seperti hasad, dengki dan sombong, ujub serta riak. ${ }^{22}$

\footnotetext{
${ }^{17}$ Florence Wedge, Mencegah Gangguan Emosional, Terj. Widyakarto dan Hadisubrata, Yogyakarta: PT. Obor, 1995, h. 53.

${ }^{18}$ H.Kaplan B, Pshychososial Sress Trend in Theory and Researce, New York: Academic Press, 1983, h. 296.

${ }^{19}$ Ahmad Fauzan, Psikologi Umum, Cet III, Bandung: Pustaka Setia, 2004, h. 54.

${ }^{20}$ Florence Wedge, Mencegah..., Ibid, h. 332.

${ }^{21}$ Muhammad Utsman Najati, Al qur'an wa 'Tlm al Nafs, Terj. Cet. 5, al Qo'hirah: dar al Shuruq, 1993, h. 73

${ }^{22}$ Muhammad Utsman Najati, Psikologi dalam Al-Qur'an: Terapi Qur'ani dalam Penyembuhan Gangguan Kejizaan, (Bandung: Pustaka Setia, 2005), h. 99.
} 
Ketika manusia dalam ketakutan akan diiringi dengan perubahan fungsi fisiologis yang tersumbat, roman muka, suara dan kosndisi fisik. Aspek emosi lain adalah penyakit hati yang mengarah pada bentuk permusuhan dan kejahatan. ${ }^{23}$

Emosi tidak selamanya bersifat negatif, tetapi bila dikaitkan dengan tema efisiensi dan efektivitas seperti dalam proses berfikir, berkonsentrasi, bertindak, menyesuaikan diri secara positif justru akan membawa dampak positif dalam pembentukan kepribadian. Jadi dapat disimpulkan tekanan emosi sebagai suatu hasil reaksi psikososial individu dalam merespon peristiwa dan pengalaman hidupnya. Dalam perkembangannya emosi meliputi berbagai respon yaitu negatif dan positif. Respon negatif inilah yang menyebabkan tekanan emosi semakin besar. Untuk mengukur emosi maka maka dapat digunakan parameter emosi yang terdiri dari Stimulus, Perasaan, Respon-respon internal dan pola-pola tingkah laku, aspek inilah yang nantinya dapat menentukan apakah seorang individu memiliki emosi negative dan positif, sehingga dengan mengetahui aspek/ komponen emosi ini individu mampu mengarahkan emosinya secara efektif dan efisien.

Tekanan emosi pada perempuan secara kualitatif lebih rendah dibandingkan dengan laki-laki. Hal ini dikarenakan, secara psikis perempuan sering dikatakan memiliki konsep dan mekanisme pertahanan diri yang tinggi dibandingkan dengan laki-laki, sehingga perempuan memiliki kecenderungan tidak mengalami tekanan emosi yang tinggi. Hasil penelitian Hasanan (2008) menyebutkan bahwa perempuan cenderung memiliki pembentukan konsep diri positif, sehingga cenderung mudah memunculkan penerimaan dan pemahaman terhadap setiap permasalahan yang dihadapi. Sedangkan laki-laki cenderung sukar menemukan mekanisme pertahanan diri, dan cenderung mengalami tekanan emosi yang hebat. Perempuan dalam struktur kepribadiannya dikatakan memiliki respon positif dalam menyalurkan setiap emosinya melalui menangis, tertawa, marah, dan lain sebagainya. Sedangkan laki-laki cenderung tidak mampu menyalurkan emosinya secara tepat, sehingga mengakibatkan tekanan emosi yang cukup hebat, dan berakhir pada kondisi frustasi dan atau depresi.

${ }^{23}$ Ibid, h. 120. 


\section{Pengaruh Komunikasi Interpersonal dalam Menurunkan Problem Tekanan Emosi}

Dikatakan bahwa sumber kehidupan manusia sebagai makhluk sosial adalah berkomunikasi. Dengan berkomunikasi seorang indivudu dapat memenuhi segala kebutuhan hidupnya baik kebutuhan fisiologis maupun kebutuhan psikologis. Komunikasi interpersonal sebagai salah satu bentuk komunikasi yang sering dilakukan dan mudah dijumpai nampaknya melibatkan fungsi terapiutik dan sinamika psikososial yang berfungsi untuk meningkatkan perkembangan kepribadian dan kematangan jiwa seseorang. ${ }^{24}$ Selanjutnya dapat dikatakan komunikasi interpersonal yang efektif mampu melahirkan rasa kepercayaan dinamika psiko-sosio-religius pada manusia.

Dengan adanya dinamika ini, diharapkan individu mampu mengoptimalkan potensinya untuk selalu menghadirkan nilai positif dalam dirinya, sehingga individu dapat mengurangi beban psikologis yang dihadapinya. Dengan kata lain komunikasi interpersonal dapat dijadikan upaya untuk mengurangi ketegangan hidup. Ketegangan yang dihadapi individu biasanya berkaitan dengan ketegangan emosi. Hal ini dikarenakan ketegangan emosi merupakan salah satu bentuk ketegangan yang sering dihadapi manusia berupa rasa takut, cemas, khawatir, senang, benci dan lain sebagainya. Ancok memnyebutkan bahwa ketegangan emosi berupa cemas, was-was, khawatir, senang, benci dan marah bisa menyerang pada siapapun tanpa memandang batas usia, strata sosial maupun tingkat pendidikan. ${ }^{25}$

Agar ketegangan emosi ini tidak berkembang menjadi lebih kuat, maka diperlukan upaya komunikasi interpersonal yang intens dan diarahkan menuju komunikasi interpersonal yang efektif. Oleh karena itu maka komunikasi interpersonal diduga kuat dapat mengurangi ketegangan emosi individu dan cenderung melahirkan dinamika psiko-emosional dan psikososio-religius yang lebih positif. Salah satu penelitian yang dilakukan oleh Nashori mengenai komunikasi interpersonal ditinjau dari kematangan

\footnotetext{
${ }^{24}$ Stave Duck, Interpersonal Communication: In Developing Acquantance, (London: Sage Publications, 1983), h. 128.

25Jamaludin Ancok, Psikologi Islam, (Yogyakarta: Pustaka Setia, 2010), h. 42.
} 
beragama dan konsep diri menjelaskan bahwa komunikasi interpersonal merupakan salah satu bentuk komunikasi yang dapat melahirkan keterbukaan, kesadaran sosial, kesepahaman, perasaan empatik, dan mengurangi ketegangan akibat beban mental secara kontinu. Hasil penelitian ini menyebutkan bahwa aspek keterbukaan yang terjadi dalam dinamika komunikasi interpersonal ternyata sangat dipengaruhi konsep diri dan kematangan individu. ${ }^{26}$

Komunikasi interpersonal yang efektif pada diri seorang dapat menimbulkan kepercayaan dan rasa aman, sehingga dengan proses komunikasi tersebut muncul respon-respon kejiwaan berupa keterbukaan dan kenyamanan menyampaikan ide, dan selanjutnya mereka akan mendapatkan dampak positif berupa rasa bahagia, senang, terlindungi, memiliki kerabat, terhindar dari perasaan takut, khawatir dan tegang. Dinamika psikologis yang terjadi pada komunikasi interpersonal berupa aspek keterbukaan dan rasa percaya ternyata memiliki dampak berkurangnya tekanan emosional dan beban mental dalam dirinya.

Hasanat (1996) menyebutkan bahwa komunikasi (interpersonal) dalam keluarga yang dilakukan secara intens akan mempengaruhi kualitas perilaku dan rasa aman pada anggota keluarga lainnya, khususnya pada anak..$^{27}$ Kualitas perilaku dan rasa aman yang ditimbulkan dari hubungan komunikasi interpersonal ini akan menciptakan iklim emosi yang dinamis dan bersifat menyenangkan (pleasant emotion). ${ }^{28}$ Apabila seseorang menemukan iklim emosi yang menyenangkan maka mereka akan mampu menekan beban mental-emosionalnya dan selanjutnya akan melahirkan perilaku yang positif. Berdasarkan hal tersebut maka dapat dijelaskan bahwa dinamika psikis komunikasi (interpersonal) yang banyak dilakukan pada akhirnya akan melahirkan iklim emosi positif sehingga akan mengurangi beban emosi yang membelenggu jiwa individu seperti perasaan sedih, mali, benci, kalah, terancam dan lain sebagainya.

\footnotetext{
${ }^{26}$ Fuad Nashori, "Komunikasi Interpersonal Ditinjau dari Kematangan Beragama dan Konsep Diri", Tesis, (tidak dipubllikasikan), Yogyakarta: UGM, 2000, h. 19.

${ }^{27}$ Nidaul Hasanat, "Bagaimana Komunikasi dalam Keluarga Pasien Gangguan Jiwa? Suatu Kajian tentang Expressed Emotion." Handout seminar, 1996, h. 3.

${ }^{28}$ Wisnu Sri Hertinjung dan Partini, "Gangguan Perilaku pada Anak SD Ditinjau dari Ekspresi Emosi Ibu", Jurnal Dinamika Sosial Ekonomi Volume 6 Nomor 1 Edisi Mei 2010,UMS Surakarta, h. 6.
} 
Sedangkan menurut Rakhmad (2001), apabila suasana komunikasi interpersonal terjalin dengan baik maka akan menimbulkan persahabatan yang tinggi, mereka saling melakukan tukar respon emosional secara aktif, dan berdampak pada efektivitas menurunkan tegangan akibat peristiwa yang dialaminya. Sebagaimana disebutkan oleh Sri Muulani, ruang komunikasi interpersonal dalam komunitas sehat dan dibangun oleh aspek persahabatan akan memicu fungsi terapis berupa rasa empati yang dapat dirasakan orang lain, sehingga seorang itu akan mampu menemukan alternatif problem solving yang berguna untuk memecahkan permasalahan yang dihadapi teman/ sahabatnya. ${ }^{29}$ Dinamika terapi ini dapat dilakukan untuk mengelola perasaan emosi dan selanjutnya dapat mengambil keputusan pemecahan masalah yang dihadapi secara mandiri. Masalah tersebuut dapat berbentuk tekanan emosi seperti mengurangi rasa malu, sedih, takut, khawatir, marah, benci dan sebagainya dan diarahkan kepada sesuatu yang efektif dan efisien. Dengan demikian dapat disimpulkan bahwa komunikasi interpersonal memiliki pengaruh secara signifikan dalam mengurangi problem tekanan emosi. Selanjutnya untuk menggambarkan pengaruh komunikasi interpersonal dalam menurunkan problem tekanan emosi, akan dijelaskan dengan menggunakan hasil penelitian yang disampaikan oleh Sri Mulyani (2008) komunikasi interpersonal merupakan hubungan antar manusia yang dilandasi saling pengertian sehingga tercipta jalur informasi dua arah antar pribadi yang terlibat dalam proses tersebut. ${ }^{30}$

Kemampuan sensorik dalam komunikasi interpersonal ingin mengembangkan kemampuan untuk mendengarkan, sekaligus melahirkan perhatian dan pemahaman. Pada sebagian besar perempuan cenderung dapat mengembangkan kemampuan ini dibandingkan dengan laki-laki. Perhatian dan pemahaman komunikasi interpersonal berfungsi mengembangkan visi diri-sosial maupun untuk keberartian dari pemahaman teoritik. ${ }^{31}$ Hubungan yang dilandasi adanya saling pengertian dan memahami akan melahirkan

\footnotetext{
${ }^{29}$ Hasyim Hasanah, "Efektivitas Konseling Kelompok dalam Meningkatkan Sikap Keberagamaan Anak Usia Sekolah", Jurnal Konseling Islam, STAIN KUDUS, 2009, h. 139.

${ }^{30}$ Sri Mulyani, "Analisis Pengaruh Faktor-Faktor Kecerdasan Emosi terhadap Komunikasi Interpersonal Perawat Dengan Pasien di Unit Rawat Inap RSJD dr Amino Gondohutomo", (tesis tidak dipublikasikan) Semarang, 2008, h. 55-56.

${ }^{31}$ http://file.upi.edu/Direktori/FIP/JUR._ADMINISTRASI_PENDIDIKAN/ 195908141985031 -JOHAR_PERMANA/Tek_Kom_Inter_Pers_Modul.pdf
} 
perasaan aman, perhatian, umpan balik yang positif dan akhirnya mampu mengurangi dampak perasaan negatif dalam diri seseorang. Selanjutnya perasaan negatif itu akan diarahkan kepada perilaku yang lebih efektif dan efisien. Apabila seseorang mampu menemukan aspek positif dari perasaan (emosi) negatifnya, maka mereka akan mampu mengurangi beban psikologis dan tekanan yang dialaminya. Lebih lanjut dijelaskan bahwa komunikasi interpersonal akan membentuk dinamika psikologis yang harmonis, artinya apabila komunikasi dilakukan dengan perasaan senang, maka akan melahirkan sikap terbuka, mendengar dengan penuh perhatian, timbul prasangka positif dan melahirkan hubungan sosial lebih intens, sebaliknya apabila komunikasi antar pribadi/ interpersonal dilakukan dengan perasaan benci, diliputi dengan prasangka justru akan melahirkan tekanan perasaan dan emosi lebih besar, dan biasanya justru menyulut adanya permusuhan, persepsi negatif dan ketidak harmonisan hubungan interpersonal.

Berdasarkan penelitian ini maka dapat diambil kesimpulan bahwa komunikasi interpersonal secara positif memberikan kontribusi dalam mengurangi beban psikologis dan menekan sumber tekanan emosi individu, selanjutnya dapat berfungsi mencapai keharmonisan sosial, membentuk emosi yang menyenagkan, keamanan dan ketenangan. Salah satu bentuk emosi yang menyenangkan akan secara otomatis mengurangi dampak tekanan emosi secara negatif. Secara kualitatif penurunan problem tekanan emosi dapat dilihat dari dinamika psikologis yang terbentuk dari pola hubungan interpersonal yang melibatkan fungsi terapi seperti adanya perasaan saling memahami, mengerti, menerima, empati, saling terbuka dan adanya mekanisme persahabatan dan pertemanan.

\section{Hasil Penelitian}

Setelah dilakukan pengujian secara terstruktur melalui angket yang disebar ke subyek penelitian didapatkan hasil bahwa terdapat problem tekanan emosi pada mahasiswa program khusus di IAIN Walisongo berupa emosi negatif meliputi perasaan khawatir, takut, tertekan, sedih, kecewa dan terdiskriminasikan. Problem emosi selanjutnya berupa lima aspek yang terdiri dari: (a) merasa terbebani dengan target program, maksudnya Mahasiswa program khusus terebani dengan target penyelesaian program tepat waktu (yaitu 8 semester) yang meliputi pembiayaan, waktu penyelesaian program dan beban kurikulum; (b) Adanya integrasi antara 
kulian dengan pembinaan khusus, artinya mahasiswa program khusus merasa terbebani dengan integrasi kuliah berbasis akademik dan non akademik berupa pembinaan ma'had dan halaqoh, sehingga mereka merasa waktu belajar menjadi kacau dan membingungkan; (c) Integrasi dwi bahasa (Arab dan Inggris), maksudnya Adanya ketentuan memiliki kemampuan/ kompetensi terhadap penguasaan bahasa asing yaitu inggris dan arab, karena mahasiswa program khusus berasal dari background pendidikan beragam seperti MA, SMA, STM, maka penguasaan bahasa asing dirasa menimbulkan tekanan bagi mahasiswa laki-laki maupun perempuan, (d) Tahfidul Qur'an. Adanya ketentuan penguasaan tahfidul Qur'an setiap mahasiswa, minimal untuk program khusus diwajibkan hafal sebagian juz dari al Qur'an, sehingga menjadikan tekanan mental bagi mahasiswa; (e) Pengelolaan program yang tidak jelas dan terlalu mengekang. Mahasiswa merasa pelaksanaan program khusus di IAIN kurang jelas, terlalu membebani, tidak transparan dan ada komunikasi yang intens dan terbuka dengan mahasiswa, sehingga problem kemahasiswaan sering tidak tertangani dengan baik, bahkan cenderung melahirkan tekanan mental yang tambah berat.

Uji kuantitatif pengaruh komunikasi Interpersonal dalam menurunkan tekanan emosi dapat ditnjukkan dari hasil uji pengaruh dan determinasi. Berdasarkan hasil perhitungan kuantitatif didapatkan hasil bahwa komunikasi interpersonal berpengaruh terhadap penurunan problem tekanan emosi dengan $F_{\text {hasi }}$ sebesar 7,966 dan lebih besar dari $F_{\text {tabel }}$ yaitu 6,302 pada taraf signifikan 0,05 . Sedangkang uji determinasi menghasilkan nilai besarnya adjusted $\mathrm{R}^{2}$ adalah 0,910 , hal ini berarti $91,0 \%$ variasi problem tekanan emosi dapat dijelaskan oleh variasi variabel independen komunikasi interpersonal, sedangkan sisanya dijelaskan oleh sebab-sebab lain di luar model. Perbedaan berdasar jenis kelamin secara simultan menunjukkan pengaruh antara variable penelitian laki-laki lebih besar dibandingkan dengan pengaruh uji variable perempuan. Hal ini dapat dilihat dari thasil lakilaki $>$ dari $t_{\text {hasi }}$ perempuan pada koefisien simultan 16,065 > 11,660.

Berdasarkan hasil penelitian didapatkan bahwa telah terjadi problem tekanan emosi pada mahasiswa program khusus di IAIN Walisongo Semarang. Tekanan yang dihadapi mahasiswa ini sebenarnya lahir dari ketidakmampuan mahasiswa laki-laki dan perempuan dalam mengarahkan 
emosinya. Emosi yang semestinya dapat dimanfaatkan untuk tema efisiensi dan efektivitas pengembangan diri, justru menjadi tekanan mental yang begitu berat. Problem tekanan emosi yang dialami para mahasiswa ini umumnya lebih mengarah pada permasalahan psikis yang disebabkan pengalaman akademik "yang kurang pro", khususnya pada kurikulum akademik dan non akademik penguasaan dan kompetensi bahasa asing. Ketentuan program yang menuntut mereka dapat memiliki kemampuan bahasa asing (Inggris dan Arab) secara integral menyulut tekanan emosi yang begitu dalam. Akibatnya mereka menjadi khawatir, cemas, takut, dan tertekan apabila mereka tidak mampu menguasai keterampilan bahasa tersebut. Selain problem bahasa asing, tekanan emosi yang dihadapi mahasiswa program khusus adalah ketentuan menghafal sebagian al Qur'an. Melihat background pendidikan mahasiswa yang beragam, maka hal ini menurut penulis juga menjadi faktor timbulnya tekanan emosi pada mahasiswa.

Selain itu ada faktor internal dan eksternal. Faktor internal disebabkan karena kondisi psikis dari para mahasiswa, sedangkan faktor eksternal lebih disebabkan karena pemberlakuan kurikulum, pengelolaan dan lingkungan. Hasil analisis faktor internal yang meliputi dimensi psikis dapat dijelaskan dari aspek "ABC" Affective, Behaviour dan Cognitive. Aspek afektif sikap konsisten terhadap tata aturan nilai, memiliki kesalehan hubungan sosial, sikap mau tahu dan aktif dalam kegiatan pengelolaan program, bertanggung jawab dengan apa yang menjadi kewajibannya dan tidak terlalu menuntut hak. Aspek behaviour atau perilaku lebih didasarkan pada pola perilaku mahasiswa, kebiasaan, perbuatan, keaktifan, kreativitas belajar, sedangkan aspek kognitif lebih pada masalah intelegensi atau kecerdasan, pengetahuan dan pemahaman serta kemampuan menerima dan menganalisis ilmu yang mereka dapatkan. Hasil analisis faktor eksternal meliputi sistem pengelolaan yang menurut mahasiswa tidak jelas dan tidak terbuka, adanya perlakuan diskriminatif, kurikulum yang dirasa cukup berat karena memadukan atau mengintegrasikan pola kurikulum akademik dan non akademik, dan selanjutnya faktor lingkungan. Dalam hal ini menurut penulis faktor lingkungan memainkan peran yang begitu besar terhadap problem tekanan emosi mahasiwa. Lingkungan dengan suasana kondusif akan membawa ketenangan dan kesejahteraan, sebaliknya lingkungan dengan suasana tidak kondusif akan semakin memperberat tekanan emosi. Dalam beberapa tema, tekanan emosi dapat berkembang menjadi peluang untuk menngkatkan 
pemahaman dan daya tahan terhadap maslah yang dihadapi, ketika seseorang dapat mengarahkan tekanan emosinya secara tepat, maka mereka akan mendapatkan semangat dan kekuatan untuk mengembangkan potensinya. Menurut hemat penulis, untuk dapat meminimalkan tekanan emosi, maka perlu upaya untuk dapat memahami inti dari tekanan emosi tersebut, sehingga emosi yang tadinya akan membawa dampak negatif justru berpeluang menjadi susmber kekuatan dan semangat untuk individu. Oleh sebab itu diperlukan upaya untuk mengelola tekanan emosi. Tekanan emosi pada sebagian besar orang dapat diminimalisir dengan membangun hubungan yang harmonis dengan orang lain. Hal ini dimaksudkan untuk dapat menyalurkan sumber tekanan yang dialaminya.

Menurut Miller, dengan melakukan komunikasi secara intens akan terbina hubungan yang harmonis dan diliputi dinamika psikologis yang begitu mendalam. ${ }^{32}$ Selanjutnya komunikasi interpersonal akan membentuk fungsi terapiutik dan dinamika psikososial yang berfungsi untuk meningkatkan perkembangan kepribadian dan kematangan jiwa seseorang. Salah satu bentuk kematangan jiwa seseorang adalah kemampuan mereka dalam mengarahkan tekanan emosi yang dihadapinya secara efektif dan efisien. Dengan asumsi bahwa komuniksi interpersonal sebagai pola hubungan interaksional jangka panjang secara simultan akan menimbulkan iklim emosi yang kondusif untuk perkembangan psikologis individu dan dapat menjadi salah satu faktor penggerak perilaku sosialnya. ${ }^{33}$

Sedangkan menurut Ekman komunikasi yang efektif antara individu akan membentuk jiwa dinamis dan selalu mengarahkan emosi positifnya secara integral, yang didukung orientasi religiusnya untuk menghadirkan nilai-nilai positif, sehingga kebahagiaan hidup dapat dicapai secara optimal.34 Lebih lanjut dikatakan bahwa orang yang selalu menjalinn komunikasi interpersonal mampu mengurangi konflik pribadinya karena mereka mampu menyalurkan perasaan dan tekanan yang dialamiya. Apabila seseorang telah mampu menyalurkan perasaan dan tekanan, maka secara psikis akan terbentuk mekanisme pertahanan diri secara mandiri. Problem tekanan mental

\footnotetext{
${ }^{32}$ Gerald R Miller, Exploration in Interpersonal Communication, h. 279.

${ }^{33}$ Wisnu Sri Hertinjung dan Partini, "Gangguan Perilaku pada Anak SD Ditinjau dari Ekspresi Emosi Ibu", h. 3.

${ }^{34}$ Ekman P. "Basic Emotions." in T. Dalgleish and M. Power (eds.), Handbook of Cognition and Emotion. (UK: John Wiley \& Sons Ltd, Sussex, 1999), h. 227.
} 
dan emosi negatif dapat diminimalisir dan selanjutnya individu mampu menemukan problem solving secara tepat. Senada dengan pandangan tersebut Castelli (2005) dalam penelitiannya menyebutkan bahwa dengan adanya respon komunikasi secara interns pada anak dengan autistik yang mengalami kesulitan dalam mengenali emosi orang lain akan menyebabkan mereka mampu mengekspresikan emosinya, apalagi melakukan kontak emosi dengan orang lain. ${ }^{35} \mathrm{Hal}$ ini apabila dikaji lebih dalam menunjukkan bahwa efektivitas komunikasi interpersonal pada diri individu terbukti dapat menurunkan problem tekanan emosi secara positif.

Dalam beberapa penelitian disebutkan bahwa pada umumnya perempuan memiliki kecenderungan lebih baik dalam mengembangkan komunikasi interpersonal dan menyalurkan emosinya secara positif. Hal ini ditunjukkan dalam penelitian Steve Duck (1983) yang mengatakan bahwa perempuan memiliki kecenderungan untuk lebih mampu menjalin hubungan interpersonal secara intim dan luas dibanding dengan laki-laki, hal ini dikarenakan perempuan mampu mengekspresikan emosinya lebih baik dibanding laki-laki, perempuan juga ditengarai lebih mengedepankan perasaan, empati dan kasih sayang dari pada laki-laki. ${ }^{36}$ Dengan kata lain perempuan dikatakan memiliki kemampuas psikososial. Karena perempuan lebih mengedepankan aspek psikososialnya dalam menjalin interaksi maka tidak dipungkiri perempuan memiliki kemampuan dalam membina hubungan komunikasi secara harmonis dan menyalurkan emosinya secara positif. Penelitan lain menyebutkan bahwa perempuan lebih dapat melakukan pertahanan diri dibandingkan dengan laki-laki, hal ini dikarenakan perempuan memiliki kemampuan psikologis mengelola emosinya dan memiliki tingkat stress lebih rendah dibanding laki-laki, mereka lebih terbuka, lebih mengayomi dan menjadikan pengalaman hidup sebagai kekuatan mencapai kebahagiaan. Perempuan lebih peka dalam merasakan sesuatu dan leluapkan perasaannya. ${ }^{37}$

Sedangkan menurut Planalp ada kecenderungan laki-laki mengabaikan emosinya, karena emosi dianggap sebagai sesuatu yang tidak penting dalam

${ }^{35} \mathrm{~F}$. Castelli, “Understanding Emotions from Standardized Facial Expression in Autism and Normal Development."dalam situs: Sage Publication and National Autistic Society, www.sage publication.com.diakses tanggal 20 Oktober 2011.

${ }^{36}$ Stave Duck, Interpersonal Communication: In Developing Acquantance, h., 42.

${ }^{37}$ J.E. Prawitasari, "Apakah Wanita Lebih Peka Daripada Pria dalam Mengartikan Emosi Dasar Manusia?"' Jurnal Psikologi, UGM, Yoryakarta No. 1, 1993, h. 14-15. 
kehidupannya. ${ }^{38}$ Bagi sebagian besar laki-laki menganggap bahwa yang lebih penting adalah bagaimana kehidupannya, bagaimana memikirkan pemenuhan terhadap kebutuhannya, karir pekerjaan, pendidikan dan pemenuhan terhadap keterampilan yang berhubungan dengan aspek kelangsungan hidup. Oleh sebab itulah maka laki-laki dianggap sebagai pribadi yang tidak mau peduli dengan emosi yang mereka alami. Laki-laki cenderung menarik diri dari lingkaran emosi yang dialaminya. Dalam beberapa hal kondisi ini membawa dampak negatif bagi perkembangan emosi laki-laki.

Biasanya implikasi yang ditimbulkan dari ketidak-pedulian terhadap reaksi emosi laki-laki berdampak tidak hanya secara psikis melainkan juga fisik. Secara fisik laki-laki cenderung memiliki rentang usia yang rendah dibandingkan perempuan, selain itu laki-laki juga mudah terserang penyakit fisik senso-neurotik, penyakit disfungsi jantung, hati dan paru. Berbeda dengan perempuan, aspek afektif dalam kehidupan seorang perempuan memainkan peran lebih dalam struktur kepribadiannya, sehingga perempuan lebih pandai mengungkapkan perasaan, lebih bisa mengarahkan sikap, lebih bisa mengelola hubungan dan lebih bisa beradaptasi dengan permasalahan.

Berbeda dengan penelitian para ahli komunikasi, penelitian ini justru mendapatkan kenyataan bahwa laki-laki lebih dapat berperan dan membina komunikasi interpersonal dan mengurangi tekanan emosi dibandingkan dengan perempuan. Hasil ini menunjukkan perbedaan dengan konsep teori pada umumnya yang mengatakan bahwa perempuan cenderung dapat membina hubungan komunikasi dan menurunkan tekanan emosinya dibandingkan dengan laki-laki. Analisis yang dapat penulis kemukakan di sini adalah telah terjadi proses belajar sosial (learning social) yang dilakukan kaum laki-laki pada komunitasnya. Menurut teori psikologi disebutkan bahwa seseorang yang hidup dalam lingkungan sosial tertentu akan melakukan pembelajaran sosial secara kontinu, sehingga melahirkan persamaan, keharmonisan dan prilaku pro-sosial. Laki-laki maupun perempuan memiliki kemampuan untuk mempresentasikan dan menafsirkan seluruh pengalaman hidupnya. Mereka yang memiliki kemampuan untuk dapat mengakumulasi seluruh nilai dan pengalaman kehidupannya akan

38S. Planalp, Communicating Emotion: Sosial, Moral, and Cultural Proccesses, (Cambridge: Cambridge University, 1999, h. 451. 
jauh memiliki kemudahan dan mencapai kematangan jiwa dibandingkan dengan mereka yang tidak memiliki kemampuan tersebut.

Selanjutnya dapat penulis katakan bahwa mahasiswa laki-laki program khusus di IAIN memiliki kemampuan untuk mencapai learning sosial secara positif, dan selanjutnya melalui proses komunikasi interpersonal yang efektif mereka akan mampu mengurangi problem tekanan emosi. Penelitian ini didukung oleh pendapat Hasanah (2010) yang menyatakan bahwa untuk dapat mengurangi problem tekanan emosi, setiap individu harus berada pada suasana dan situasi yang kondusif sehingga terbina keharmonisan dan perasaan keamanan dan ketenangan batiniahnya. Suasana kondusif akan menjadi dinamisator dalam proses pembelajaran pada diri manusia. Pada sebagian orang upaya untuk mengurangi tekanan emosi dilakukan dengan cara memanfaatkan pelayanan konseling kelompok yang memiliki dinamika psikologis tertentu. ${ }^{39}$ Mekanisme pembelajaran ini menurut Vygotsky didapatkan dengan cara penemuan diri sehingga akan membuat fungsi mental menjadi berkembang dan selanjutnya akan memiliki kemampuan dalam mengelola perasaan dan tekanan dalam batiniahnya. Berdasarkan hal tersebut dapat diasumsikan bahwa dengan proses pembelajaran yang dilakukan secara kontinu, individu akan mudah menemukan eksistensi dirinya, sehingga melalui pengalaman yang mereka peroleh akan dapat diarahkan untuk membentengi diri dari problematikan tekanan mental dan emosional.

Bagi sebagian perempuan mekanisme pembelajaran ini sangat diperlukan sehingga kepribadian yang melekat dalam diri perempuan dapat dioptimalkan untuk meminimalisir problem tekanan emosi yang dihadapinya, khususnya melalui optimalisasi komunikasi interpersonal secara aktif, efektif dan efisien. Mendasarkan pada kenyataan empiris di lapangan didapatkan kecenderungan bahwa laki-laki memiliki kemampuan komunikasi interpersonal yang lebih tinggi dari perempuan, selanjutnya dengan kemampuan ini dapat diarahkan untuk meminimalisir problem tekanan emosi yang datang padanya. Secara kuantitatif dapat disimpulkan bahwa terdapat perbedaan pengaruh komunikasi interpersonal dalam menurunkan problem tekanan emosi mahasiswa laki-laki dan perempuan, dimana laki-

\footnotetext{
${ }^{39}$ Hasyim Hasanah, "Efektivitas Konseling Kelompok dalam Menurunkan Problem Tekanan Emosi Anak Usia Sekolah: Analisis pendekatan interaksional Behavior", Jurnal Konseling Islam, No. 2, Vol..2, STAIN Kudus, 2010
} 
laki lebih bisa mengurangi problem tekanan emosi melalui komunikasi interpersonal dibandingkan dengan mahasiswa perempuan.

\section{Kesimpulan}

Mendasarkan berbagai data yang diperoleh di lapangan dengan menggunakan kuesioner, maka hasil penelitian ini bisa menyimpulkan (1) terdapat pengaruh komunikasi interpersonal dalam menurunkan probem tekanan emosi mahasiswa, (2) terdapat perbedaan pengaruh komunikasi interpersonal dalam menurunkan problem tekanan emosi mahasiswa lakilaki dan perempuan. Individu perlu meningkatkan komunikasi interpersonal dalam upaya menurunkan problem tekanan emosi. Pada penyelenggaraan program khusus, pengelola program dalam hal ini fakultas di lingkungan IAIN perlu melakukan upaya nyata agar mahasiswa program khusus mampu menjalin komunikasi interpersonal yang efektif sehingga mahasiswa mampu mengarahkan emosinya dengan tema-tema efisiensi. Lebih dari itu, perlu memprioritaskan masalah perbaikan sistem pengelolaan khususnya aspek akademik dan non akademik, sebagai unsur terpenting peningkatan prestasi belajar sehingga mahasiswa menjadi pribadi yang sehat mental, tidak tertekan dan memiliki semangat menyelesaikan program dengan baik. Selain itu perlu ada peninjauan kebijakan pengelolaan sehingga mampu menyelesaikan permasalahan yang dihadapi mahasiswa program khusus di IAIN baik kebijakan akademik dan non akademik (pembinaan khusus dan ma'had). Selain itu juga perlu ada mekanisme serta sistem perekrutan calon mahasiswa yang benar-benar mempertimbangkan aspek kualitas input mahasiswa program khusus di IAIN Walisongo Semarang.]

\section{Daftar Pustaka}

Ancok, Jamaludin, Psikologi Islam, Yogyakarta: Pustaka Setia, 2010.

Booklet Panduan Penyelenggaraan Program Beasiswa Penguatan Progra Studi Kajian Khusus Keislaman Direktorat Pendidikan Tinggi Islam Direktorat Jenderal Pendidikan Islam Departemen Agama RI, Tahun 2009 dalam http://www.ditpertais.net.

Buku Panduan Program Khusus Penyuluh Agama (PKPA) Fakultas Dakwah, 2009. 
Buku Panduan Fakultas Ushuluddin Program Khusus (FUPK) IAIN Walisongo Semarang, 2009.

Brooks, William D., Speech Communication, Debuque: Wm. C. Brown Company Publishers, 1974.

Brooks dan Emmert, Interpersonal Communication, Dubuque: Wm.C Brown Company Publisher, 1977.

Burn, RB., Konsep Diri: Teori, Pengukuran, Perkembangan dan Perilaku, (terj), 1993

Bustaman, H. Dj., Integrasi Psikologi dengan Islam: Menuju Psikologi Islami, Yogyakarta: Pustaka Pelajar, 1995.

Castelli, Understanding Emotions from Standardized Facial Expression in Autism and Normal Development.dalam situs: Sage Publication and National Autistic Society, www.sage publication.com.diakses tanggal 20 Oktober 2011.

Devito, Joseph A. Human Communication, 1996; Alih bahasa oleh Maulana, Agus, Komunikasi Antar Manusia. Jakarta: Professional Books,1997. , The Interpersonal Communication, Sixth Edition. New York: Harper Collins Publishers, 1992.

Duck, Stave, Interpersonal Communication: In Developing Acquantance, London: Sage Publications, 1983.

Ekman P. "Basic Emotions". in: T. Dalgleish and M. Power (eds.), Handbook of Cognition and Emotion. John Wiley \& Sons Ltd, Sussex, UK, 1999. , The Nature of Emotion, Oxford, UK: Oxford, University Press, 1994.

Effendi, Onong Utjana, Imu Komunikas: Teori Komunikasi dan Praktek, Bandung: PT. Rosdakarya, 1996.

Fauzan, Ahmad, Psikologi Umum, Cet. III, Bandung: Pustaka Setia, 2004.

Fauziah, dkk, Psikologi Dakwah, Bandung: Pustaka Setia, 2009.

Ghazali, Imam, Aplikasi Analisis Multivariate dengan Program SPSS, Semarang: BPUD, 2006.

Hasanah, Hasyim, "Efektivitas Konseling Kelompok dalam Mengurangi Tekanan Emosi Anak Usia Sekolah", Jumal Konseling Islam, STAIN KUDUS, 2009.

Hasanat, Nidaul, "Bagaimana Komunikasi dalam Keluarga Pasien Gangguan Jiwa? Suatu Kajian tentang Expressed Emotion". Handout Seminar, 1996. 
Hertinjung, Wisnu Sri dan Partini, "Gangguan Perilaku Pada Anak SD Ditinjau dari Ekspresi Emosi Ibu," Jumal Dinamika Sosial Ekonomi Volume 6 Nomor 1 Edisi Mei 2010, UMS Surakarta.

Hovland, C.I \& W. Weiss, The influence of Source Credibility on Communication Effectivennes, POQ, 15, 1951.

Hurlock, E.B, Psikologi Perkembangan: Suatu Pendekatan sepanjang Rentang Kehidupan, (terj.), Jakarta: Erlangga, 1991

Jalaluddin Rahmad, Psikologi Komunikasi, Bandung: PT. Rosdakarya, 2000.

Kelly, G, The Pshycology of Personal Construct, Lincoln: University of Nebrasca Press, 1976.

Kafie, Jalaludin, Psikologi Dakwah, Surabaya: PT. Indah Offset, 1993.

Kaplan, H., Psychology Stress Trend In Theory And Research, NewYork: Academic Press, 1983

Kotter, et.al dalam Arthur Jersild, Child Psychology, Fourth Edition, New Delhi: Prentice-Hall, Inc, 1997.

Littlejohn, Stephen, Theories of Human Communication, Edisi V, California: Wadsworth, 1996.

Mangkuatmodjo, Soegyarto, Statistik Lanjutan, Jakarta: Rineka Cipta: 2004.

Maryani, Rosley, Psikologi Umum, Bandung: Pustaka Setia, 2010.

McDonagh, Expressed emotion as a precipitant of relapse in psychological disorder. Classroom Leadership. Vol. 7, 2003.

Miller, Gerald R, Exploration in Interpersonal Communication, London: SAGA Publikations, 1989.

Mulyana, Dedy, Ilmu Komunikasi, Bandung: PT. Rosdakarya, 2002.

Mulyani, Sri, "Analisis Pengaruh Faktor-faktor Komunikasi interpersonal terhadap Komunikasi Interpersonal Perawat dengan Pasien di Unit Rawat Inap RSJD dr Amino Gondohutomo", Tesis, (dipublikasikan) Semarang, 2008.

Najati, Muhammad Utsman, al-Qur'an wa Tlm al-Nafs, terj. Cet. V, al-Qahirah: Dar al-Shuruq, 1993.

, Psikologi dalam al-Qur'an: Terapi Qur'ani dalam Penyembuhan Gangguan Kejiwaan, Bandung: Pustaka Setia, 2005. 
Pearce, W.B, "Consensual Rule in Interpersonal Communications and Relationship", Joumal of Communication, No. 23, 1973.

Panduan Pengelolaan Program Studi Khusus Kajian Keislaman, Dirjen Pendidikan Tinggi Islam Kementerian Agama RI, 2009.

Planalp, S., Communicating Emotion: Social, Moral, and Cultural Processes, Cambridge: Cambridge University, 1999.

Prawitasari, J.E., "Apakah Wanita Lebih Peka daripada Pria dalam Mengartikan Emosi Dasar Manusia?" Jumal Psikologi, UGM, Yoryakarta No. 1, 1993.

Prabowo, Hendro, dkk., "Analisis Ekspresi Wajah Berbantu Media Cetak, Internet dan Software", Jurnal Proceedings, Komputer dan Sistem Intelijen (KOMMIT), Universitas Gunadarma, Jakarta, 2004.

Santoso, Slamet, Teori-teori Psikologi Sosial, Yogyakarta: Galia, 2009.

Rakhamad, Jalaluddn, Psikologi Komunikasi, Bandung: Remaja Rosdakarya, 2001.

Sobur, Alex, Psikologi Umum, Bandung: Pustaka Setia, 2003.

Santosa, Singgih, Buku Latian SPSS Statistik Parametrik, Jakarta: PT. Elex Media Komputindo, 2002. , Analisis Regresi, Jogjakarta: Penerbit Andi, 2004.

Sugiono, Statistika Untuk Penelitian, Bandung: Alfa Beta, 2000.

Sugiyono, Metode Penelitian Pendidikan: Pendekatan Kualitatif, Kuantitatif dan R\&D, Jakarta: Alfabeta, 2009.

Susetya, Budi, Stereotip dan Relasi Antar Kelompok, Yogyakarta: Graha Ilmu, 2010.

Taylor dan Moghaddam, Theories of Intergroup Relations, London: Praeger, 1994.

Tulus, Winarsunu, Statistika dalam Penelitian Psikologi dan Pendidikan, Malang: UMM Press, 2004.

Wedge, Florence, Mencegah Gangguan Emosional, terj. Widyakarto dan Hadisubrata, Yogyakarta: PT. Obor, 1995.

Wedge, Florance, Mencegah Gangguan Emosional, disadur oleh Jc. Widyokartono dan MS Hadisubrata, Jakarta: Obor, 1995.

Wolman, Benyamin B, Interpersonal Communication, Boston: Houghton Mifflin.Co, 1973. 
